\title{
PENGARUH LUAS LAHAN TERHADAP PENDAPATAN USAHATANI KEDELAI DI KECAMATAN TOARI KABUPATEN KOLAKA
}

\author{
Yuli Purbaningsih ${ }^{1^{*}}$ \\ ${ }^{1}$ Universitas Sembilanbelas November Kolaka \\ ${ }^{\star}$ Corresponding author : yoeli.yoelan7@gmail.com \\ To cite this article: \\ Purbaningsih, Y. (2020). Pengaruh Luas Lahan terhadap Pendapatan Usahatani Kedelai di Kecamatan Toari \\ Kabupaten Kolaka. JIA (Jurnal IImiah Agribisnis) : Jurnal Agribisnis dan IImu Sosial Ekonomi Pertanian, 5(3), \\ 111 - 116. doi:http://dx.doi.org/10.37149/jia.v5i3.12310
}

Received: June 07, 2020; Accepted: June 27, 2020; Published: June 30, 2020

\begin{abstract}
This research aims to find out the level of technical efficiency of the use of production factors in soybean farming (Glycine max L Merrill) in Toari Sub District of Kolaka District. The research method used is quantitative research with a survey approach. The determination of samples is done by the census. The object of the study was 30 farmers as respondents. Data is collected, analyzed, collected, then explained to provide answers about the phenomenon that occurs. Then, explain the relationship, the hypothesis test, and the conclusions of the analysis obtained. The results showed that a value of 1,172 is a (constant) indicating that if there is no earth tax burden then the production rate will reach 1,172. Based on the results of data processing obtained the value of $t$ area of land by $=$ 1,274 with a probability of $0.000<0.05$ so that the area of land is significant to soybean farming income.
\end{abstract}

Keywords: agriculture area; farming; income; soybean

\section{PENDAHULUAN}

Indonesia sebagai negara pertanian di mana sebagian besar penduduk hidup dengan pertanian. Oleh karena itu, pembangunan pertanian penting, hal ini dapat dilihat dari peran sektor pertanian dalam menyediakan lapangan kerja, pasokan pangan, dan berkontribusi terhadap devisa negara melalui ekspor. Sektor pertanian masih memainkan peran penting dalam perekonomian nasional, yang ditunjukkan oleh sejumlah besar orang atau pekerja yang hidup dari pertanian (Mubyarto, 1999).

Peningkatan pendapatan nasional diperlukan adanya pemanfaatan potensi pertanian yang sebahagian basar diusahakan oleh masyarakat di pedesaan. Indonesia sangat mendukung dikembangkannya jenis tanaman pangan dan palawija, karena tanaman pangan dan palawija merupakan komoditi yang strategis sebagai sumber karbohidrat dan protein yang dibutuhkan bagi manusia (Adisarwanto, 2008).

Di Indonesia kedelai (Glycine max L Merrill.) selain untuk bahan pangan juga dijadikan sebagai bahan baku industri non pangan, disamping memiliki beberapa keuntungan dibandingkan dengan komoditas pangan lain yaitu memiliki kandungan gizi yang lebih tinggi. Dalam setiap 100 gram kedelai kering mengandung 334,90 gram protein, 331,90 gram protein, 331,00 kal kalori, 18,10 gram lemak, 7,5 gram air, 34,8 gram karbohidrat, 4,7 gram, $227 \mathrm{mg}$ kalsium, $585 \mathrm{mg}$ fosfor (Krisnawati, 2017). Kedelai dengan harga terjangkau menjadi salah satu pangan utama dengan permintaan pasar yang cukup tinggi dan permintaan tersebut tidak dibarengi dengan kemampuan pemenuhan oleh produksi nasional (Deswika \& Noor, 2017).

Kebutuhan kedelai setiap tahunnya mencapai 2 juta ton, sedangkan produksi dalam negeri hanya 0,8 juta ton pertahun. Oleh karena itu, pemerintah melakukan impor sebanyak 1,2 juta ton per tahunnya. Diperkirakan bahwa konsumsi kedelai akan selalu mengalami peningkatan seiring dengan meningkatnya konsumsi kedelai akibat pertambahan jumlah penduduk, peningkatan pendapatan, dan kesadaran akan pemenuhan gizi (Mapu dkk., 2019a). 
Kabupaten Kolaka topografi yang mendukung untuk membudidayakan tanaman semusim terutama kedelai. Hal ini berdasarkan data BPS tahun 2018 yang bersumber dari laporan statistik pertanian tanaman pangan tentang luas panen, produktivitas jagung dan kedelai Kabupaten/Kota Provinsi Sulawesi Tenggara 2015 di Kabupaten Kolaka data kedelai luas panen 891 ha, produksi $166.718,71$ ton. Dengan potensi tersebut petani dapat meningkatkan produksi dengan upaya perluasan lahan panen, hal ini berkaitan erat dengan tingkat kesejahteraan petani. Olehnya itu, kemampuan petani dalam menggunakan faktor produksi secara tepat akan mengurangi biaya produksi dan mendapatkan produksi yang optimal.

Beberapa penelitian telah dilaporkan sebelumnya mengenai bagaimana memanfaatkan faktor produksi dengan baik dan tepat agar meningkatkan produksi dan mengurangi biaya produksi tanaman kedelai pada beberapa wilayah di Indonesia, seperti Jawa Timur (Widonoto \& Arifin, 2008), Aceh (Putri dkk., 2015), Indramayu (Suciaty \& Hidayat, 2019), dan Tojo Una-Una (Mapu dkk., 2019b), penelitian (Alamanda, 2019) menyatakan bahwa usahatani kedelai rata rata produktivitas sebesar 1,31 ton/ha dengan biaya yang dikeluarkan 1,45 juta/ton memperoleh pendapatan 6,76 juta/ha dengan 95\% taraf kepercayaan. (Nuswantara dkk., 2019) hasil analisisnya menyatakan bahwa usahatani kedelai masih layak diusahakan dengan kelayakan ekonomi $R / C$ rasio $>1,478$. Hingga saat ini belum ada laporan penelitian mengenai kajian analisis efisiensi teknis pada usahatani kedelai di wilayah Kabupaten Kolaka.

\section{MATERI DAN METODE}

Lokasi penelitian ini berada di Kabupaten Toari, Kabupaten Kolaka, sebagai daerah potensial untuk tanaman kedelai. Populasi dalam penelitian ini adalah 30 petani yang menanam tanaman kedelai. Penentuan sampel dilakukan melalui sensus (sampel jenuh), berdasarkan pendapat (Arikunto, 2012), yang menyatakan bahwa jika populasi kurang dari 100 orang, semua anggota populasi sampelnya. Variabel penelitian termasuk karakteristik responden, luas tanah yang ditanami kedelai, jumlah benih, pendapatan pertanian kedelai, hasil produksi, biaya produksi, produksi pertanian, penerimaan pertanian. Penentuan jumlah pendapatan pertanian dianalisis menggunakan rumus:

Dimana:

$$
\mathrm{Pdk}=\mathrm{TRk}-\mathrm{TCk}
$$

Pdk = Pendapatan Usahatani Kedelai $(\mathrm{Rp})$

TRk = Total Revenue Usahatani Kedelai (Rp)

TCk $=$ Total Cost Usahatani Kedelai (Rp)

Analisis efek variabel independen pada variabel dependen menggunakan analisis regresi. Data yang dikumpulkan akan ditabulasi dan kemudian dianalisis secara kuantitatif yang bertujuan untuk menganalisis apakah ada efek antara luas lahan pada pendapatan petani kedelai dengan menggunakan analisis regresi sederhana dan dilanjutkan dengan uji $F$ (uji signifikasi), uji koefisien determinasi dan uji t. Persamaan regresi sebagai berikut

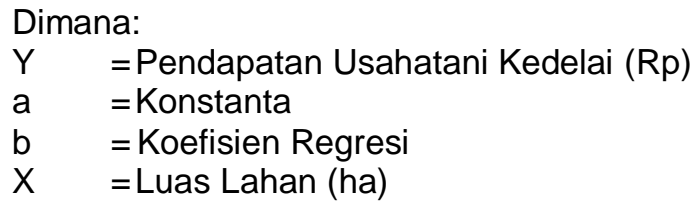

$$
\mathrm{Y}=\mathrm{a}+\mathrm{bX}
$$

\section{HASIL DAN PEMBAHASAN}

\section{Karakteristik Responden}

Pertanian kedelai yang dibudidayakan oleh petani responden terdiri dari luas kedelai yang dibudidayakan, jumlah benih yang digunakan, produksi, biaya dan pendapatan dalam satu musim panen. Semakin luas lahan yang dibudidayakan, semakin banyak masukan yang diperlukan untuk mengelola tanah dan membutuhkan lebih banyak tenaga kerja. Sementara itu, peternakan kecil membutuhkan lebih sedikit tenaga kerja dan masukan untuk mengelola peternakan mereka. Luas lahan adalah jumlah lahan yang dikelola dalam bisnis untuk menghasilkan produksi, hal ini didasarkan pada hasil penelitian oleh Tahir et al (2010) bahwa luas lahan memiliki efek positif dan signifikan pada peningkatan efisiensi teknis pertanian kedelai. Hal ini sejalan dengan hasil penelitian Kustiyani (2019) bahwa luas lahan memiliki efek yang signifikan pada produksi palawija. 
Tabel 1. Karakteristik responden

\begin{tabular}{|c|c|c|}
\hline Karakteristik & Jumlah petani (orang) & Persentase (\%) \\
\hline \multicolumn{3}{|l|}{ Luas Iahan garapan (Ha) } \\
\hline $0,5-2,0$ & 30 & 100 \\
\hline \multicolumn{3}{|l|}{ Bibit (Kg) } \\
\hline $20-40$ & 16 & 53,34 \\
\hline $41-50$ & 0 & 0 \\
\hline $51-60$ & 13 & 43,33 \\
\hline $61-70$ & 1 & 3,33 \\
\hline \multicolumn{3}{|l|}{ Produksi (Kg) } \\
\hline$<1.000$ & 5 & 16,66 \\
\hline$>1.000-1.500$ & 11 & 36,67 \\
\hline$<2.000$ & 14 & 46,67 \\
\hline \multicolumn{3}{|l|}{ Pendapatan (Rp) } \\
\hline $1.000 .000-6.000 .000$ & 16 & 53,34 \\
\hline$>6.000 .000-8.000 .000$ & 3 & 10 \\
\hline$>8.000 .000-10.000 .000$ & 11 & 36,66 \\
\hline
\end{tabular}

Sumber : Data primer diolah, 2019

Hasil pengumpulan data di lapangan menunjukkan bahwa setiap petani responden memiliki lahan yang berbeda. Luas lahan yang dibudidayakan terendah adalah 0,5 ha dan yang tertinggi adalah 1,75 ha. Tabel di atas menunjukkan bahwa responden petani memiliki luas tanah rata-rata 0,5 - 2,0 ha, yaitu 30 orang (100\%). Kondisi lahan akan mempengaruhi petani dalam pertanian mereka untuk meningkatkan produksi mereka. Hal ini sejalan dengan hasil penelitian (Widonoto \& Arifin, 2008) bahwa jika lahan yang dikelola meningkat satu hektar, produksi kedelai akan meningkat sebesar $0,45 \mathrm{~kg}$ (in elastis). Semakin luas petani dalam mengelola pertanian kedelai, semakin efisien dan menguntungkan itu akan. Demikian juga, dilaporkan oleh (Putri dkk., 2015) bahwa nilai elastisitas 0,306 berarti bahwa tambahan satu persen dari luas lahan akan meningkatkan produksi kedelai sebesar 0,306 persen. Luas lahan untuk budidaya kedelai untuk masing-masing diklasifikasikan sebagai sempit, sehingga menjadi kelemahan bagi petani, karena pertanian dengan tanah sempit tidak dapat memberikan manfaat yang cukup bagi petani dan keluarga mereka untuk hidup dengan baik jika tidak seimbang dengan pendapatan dari kegiatan bisnis ekonomi lainnya, sebaliknya. Jika semakin tinggi luas lahan untuk pertanian, maka ada kecenderungan untuk menghasilkan produksi yang lebih tinggi (Supartama et al., 2013).

Jumlah benih dalam penelitian ini adalah jumlah biji kedelai yang ditanam oleh petani di setiap tanah yang mereka miliki. Benih seperti cara lain produksi seperti pupuk, air, cahaya, iklim menentukan hasil tanaman kedelai. Meskipun ada cukup cara lain produksi yang tersedia, jika benih tidak berkualitas, maka produksi akan rendah. Kualitas benih termasuk kualitas genetik (menunjukkan identitas genetik tanaman induk), kualitas fisiologis, yaitu kelangsungan hidup benih (perkecambahan dan kekuatan pertumbuhan), dan kualitas fisik benih, yaitu munculnya bibit seperti yang terlihat secara fisik sebagai homogen dalam ukuran, baik, bersih dari campuran, bebas dari hama dan penyakit (Nuswantara et al, 2019). Keadaan jumlah benih dapat menentukan ukuran ukuran produksi dan kemampuan untuk menghasilkan setiap tanaman. Hasil penelitian menunjukkan bahwa rata-rata biji kedelai yang ditanam oleh petani responden adalah $40 \mathrm{~kg} /$ ha. Dalam Tabel 1 dapat dilihat bahwa benih yang digunakan oleh petani responden adalah 16 orang $(53,34 \%)$ menggunakan $20-40 \mathrm{~kg}$ biji, 13 orang $(43,33 \%)$ menggunakan $51-60 \mathrm{~kg}$ biji, dan 1 orang $(3,33 \%)$ digunakan $61-70 \mathrm{~kg}$ biji. Penggunaan jumlah benih tergantung pada luas lahan yang dibudidayakan oleh petani kedelai. Oleh karena itu, penggunaan jumlah benih tidak memiliki efek yang signifikan pada produksi.

Produksi pertanian adalah jumlah atau jumlah hasil yang diperoleh dari budidaya kedelai dalam satu proses produksi diukur dalam kilogram $(\mathrm{kg})$. Dalam tabel di atas, dapat dilihat bahwa responden petani memperoleh produksi $1.000 \mathrm{~kg}$ oleh 5 orang $(16,66 \%), 1.000-1.500 \mathrm{~kg}$ oleh 11 orang $(36,67 \%),<a 0>2.000 \mathrm{~kg} 14$ orang $(46,67 \%)$. Jumlah produksi yang diperoleh petani akan menentukan keberhasilan dalam mengelola pertanian mereka, dari hasil penelitian terlihat bahwa ada perbedaan dalam produksi yang diperoleh petani. Kustiyani (2019) menyatakan bahwa keuntungan dari rasio biaya lebih dari 2 diperoleh dengan produksi yang tinggi.

Pendapatan pertanian adalah perbedaan antara total pendapatan yang diterima dan total biaya produksi yang dikeluarkan oleh petani kedelai dalam satu proses produksi pertanian. Tabel di atas menunjukkan bahwa petani kedelai memiliki pendapatan yang berbeda, responden yang memperoleh Rp. 1.000 .000 - 6.000 .000 sebanyak 16 orang (53,34\%), dengan pendapatan Rp. 6.000 .000 - 8.000.000, sebanyak 3 orang (10\%), dengan pendapatan sebesar 8.000.000 - 
10.000.000 sebanyak 11 orang (36,66\%), dan tidak ada responden yang memiliki pendapatan sebesar Rp. 10.000 .000 perbedaan pendapatan ini disebabkan oleh wilayah lahan yang berbeda dan hasil produksi yang berbeda.

\section{Analisis Biaya dan Pendapatan}

Menghitung biaya budidaya kedelai yang dilakukan oleh petani, itu adalah biaya yang dikeluarkan langsung oleh petani, yang diukur dalam rupiah (Rp). Hasil penelitian menunjukkan bahwa biaya yang dikeluarkan oleh petani dalam budidaya kedelai terkait dengan biaya dalam Tabel 2 di bawah ini:

Tabel 2. Keadaan jumlah biaya yang dikeluarkan petani dalam usahatani kedelai di Kecamatan Toari Kabupaten Kolaka

\begin{tabular}{lc}
\hline \multicolumn{1}{c}{ Jenis Biaya } & Biaya Rata - Rata \\
\hline Penggunaan benih & 365.333 \\
Penggunaan pestisida & 1.630 .833 \\
Penggunaan pupuk & 241.667 \\
Penyusutan alat & 304.713 \\
Tenaga kerja & 1.353 .333 \\
Pajak lahan & 25.667 \\
\hline
\end{tabular}

Sumber : Data primer diolah, 2019

Pada Tabel 2. dengan biaya penggunaan benih kedelai rata-rata sebesar Rp. 365.333, biaya penggunaan pestisida sebesar Rp. 1.630.833, biaya penggunaan pupuk sebesar Rp. 241.667, biaya penyusutan alat sebesar Rp. 304.713, biaya tenaga kerja sebesar Rp. 1.353 .333 , dan biaya pajak lahan sebesar Rp. 25.667, dengan demikian total biaya yang dikeluarkan petani responden secara rata - rata untuk luas lahan 1,1 ha adalah sebesar Rp. 3.921.546. Hal ini sejalan dengan penelitian (Nuswantara et al, 2019) bahwa Penggunaan input produksi pada usahatani kedelai ini memiliki keragaan dan dinamika yang agak berbeda dibandingkan tanaman pangan lain seperti: padi dan jagung. Pendapatan rata-rata petani responden dari usahatani kedelai di hitung melalui analisis pendapatan. Lebih jelasnya dapat di lihat pada Tabel 3.

Tabel 3. Rata - rata pendapatan petani responden usahatani kedelai di Kecamatan Toari Kabupaten Kolaka

\begin{tabular}{lcc}
\hline \multicolumn{1}{c}{ Uraian } & Total $(\mathrm{Rp})$ & Rata - Rata $(\mathrm{Rp})$ \\
\hline Penerimaan & 300.090 .000 & 10.003 .000 \\
Biaya & 111.587 .901 & 3.728 .597 \\
Pendapatan & 188.502 .099 & 6.274 .403 \\
\hline
\end{tabular}

Sumber : Data primer diolah, 2019

Berdasarkan analisis yang digunakan di atas, diperoleh bahwa pendapatan rata-rata peternak responden dari budidaya kedelai yang dikelola adalah $\mathrm{Rp}$. 10.0003.000 dan biaya rata-rata yang dikeluarkan untuk bisnis ini adalah Rp. 3.728.597 sehingga pendapatan rata-rata petani responden adalah Rp. Hal ini sejalan dengan penelitian (Nuswantara et al, 2019) bahwa pendapatan yang diperoleh oleh petani kedelai dipengaruhi oleh sejumlah besar produksi kedelai yang diproduksi dan harga jual kedelai yang diterima oleh petani sehingga semakin besar produksi kedelai dan harga jual kedelai, semakin ada juga sejumlah besar pendapatan yang akan diperoleh oleh petani kedelai yang dapat meningkatkan pendapatan pertanian kedelai sehingga layak untuk dibudidayakan diusahakan seperti yang dikemukakan oleh Nuswantara et al (2016) ; Styawan et al (2018) ; Kurnia et al (2019) bahwa usatani kedelai layak untuk diusahakan.

Tabel 4. Hasil analisis regresi variabel luas lahan terhadap pendapaan usahatani kedelai di Kecamatan Toari Kabupaten Kolaka

\begin{tabular}{cccccc}
\hline No & Indikator & Nilai Koefisien Regresi & $\mathrm{t}-$ hitung & \multicolumn{2}{c}{ Signifikansi } \\
\hline 1. & Konstanta & 1.172 & 3.194 & .003 & ${ }^{* *}$ \\
2. & Lahan & 1.274 & 15.205 & .000 & ${ }^{* *}$ \\
\hline $\mathrm{R}^{2}$ & & & & 0,894 \\
\hline $\mathrm{R}$ (Koefisien korelasi) & & & & 0,945 \\
\hline F Hitung & & & & 231.198 \\
\hline
\end{tabular}


Tabel 4. Hasil analisis regresi variabel luas lahan terhadap pendapaan usahatani kedelai di Kecamatan Toari Kabupaten Kolaka

\begin{tabular}{llcc}
\hline No $\quad$ Indikator & Nilai Koefisien Regresi & $t$ - hitung & Signifikansi \\
\hline F Signifikansi & & $0,000^{\mathrm{a}}$ \\
\hline Keterangan: & & \\
$* *$ & $=$ Signifikan $(\alpha=0,05)$ & & \\
ts $=$ Tidak signifikan & & &
\end{tabular}

Hasil analisis menunjukkan nilai koefisien korelasi simultan $(R)=0,945$, yang berarti bahwa hubungan antara luas lahan dengan pendapatan usahatani kedelai berbentuk positif dan sangat erat. Hasil analisis diperoleh pula nilai koefisien determinasi $\left(R^{2}\right)=0,894$, hal ini berarti sebesar $89,4 \%$ keragaman pendapatan usahatani kedelai dipengaruhi oleh variabel luas lahan $\left(\mathrm{X}_{1}\right)$ Dengan demikian masih ada variabel lain yang mempengaruhi pendapatan yang tidak dimasukkan dalam model persamaan sebesar $10,6 \%$. Berdasarkan hasil uji t diketahui nilai koefisien regresi variabel luas lahan sebesar 1.274 dan berpengaruh signifikan terhadap pendapatan usahatani kedelai yang berarti bahwa jika luas lahan meningkat sebesar 1 ha akan meningkatkan pendapatan usahatani kedelai sebesar 1.274 juta. Persamaan hasil analisis di atas adalah $Y=1,172+1,274 X 1$. Nilai 1.172 adalah (konstan) yang menunjukkan bahwa jika tidak ada biaya pajak tanah, tingkat pendapatan akan mencapai 1.172.

\section{KESIMPULAN}

Luas lahan memiliki efek yang signifikan terhadap pendapatan petani kedelai di Kecamatan Toari, Kabupaten Kolaka, Sulawesi Tenggara yang ditunjukkan dengan nilai koefisien korelasi simultan $(R)=0,945$, yang berarti bahwa hubungan antara luas lahan dan pendapatan pertanian kedelai positif dan sangat dekat. Hasil penelitian ini dapat menjadi referensi bagi petani kedelai di Kabupaten Toari dalam meningkatkan produksi mereka.

\section{REFERENSI}

Adisarwanto, P. D. I. T. (2008). Kedelai Tropika Produktivitas 3 ton/ha. Penebar Swadaya Grup.

Alamanda, P. (2019). Analisis Pendapatan Dan Biaya Pokok Usahatani Kedelai Di Kecamatan Ambarawa Kabupaten Pringsewu. Universitas Lampung.

Arikunto, S. (2012). Prosedur Penelitian Suatu Pendekatan Praktik (Edisi Revisi VI) / Perpustakaan FIS. PT Rineka //library.fis.uny.ac.id\%2Fopac\%2Findex.php\%3Fp\%3Dshow_detail\%26id\%3D1167

Deswika, F., \& Noor, T. I. (2017). Analisis Pendapatan Usahatani Kedelai Polong Tua Dan Polong Muda Di Kecamatan Jatiwaras, Kabupaten Tasikmalaya, Jawa Barat. Jurnal IImiah Mahasiswa Agroinfo Galuh, 3(2), 282-290. https://doi.org/10.25157/jimag.v4i2.728

Krisnawati, A. (2017). Soybean as Source of Functional Food. Iptek Tanaman Pangan, 12(1), Article 1. http://ejurnal.litbang.pertanian.go.id/index.php/ippan/article/view/7591

Kurnia, R., Noor, T. I., Wulandari, E., \& Rachmadi, M. (2019) Kelayakan Usahatani Kedelai Di Lahan Darat Dan Lahan Sawah. Mimbar Agribisnis Jurnal Pemikiran Masyarakat Ilmiah Berwawasan Agribisnis. Juli 2019. 5(2): 346-354

Kustiyani. (2019). Pengaruh luas lahan, tenaga kerja dan pdrb terhadap Produksi palawija di jawa tengah. http://eprints.ums.ac.id/73241/. http://v2.eprints.ums.ac.id/archive/etd/73241

Mapu, C. F., Antara, M., \& Muis, A. (2019a). Analisis Pendapatan Usahatani Kedelai di Desa Balingara Kecamatan Ampana Tete Kab Tojo Una-Una. Jurnal Pembangunan Agribisnis (Journal of Agribusiness Development), 1(2), Article 2. http://jurnal.untad.ac.id/jurnal/index.php/jpa/article/view/12148

Mubyarto. (1999). Pengantar ekonomi pertanian. LP3ES. Jakarta.

Nuswantara, B., Prihtanti, T. M., Banjarnahor, D. R. V., Suprihati, S., \& Nadapdap, H. J. (2019). Kelayakan Ekonomi Usahatani Kedelai Varietas Grobogan di Kabupaten Semarang. Unri Conference Series: Agriculture and Food Security, 1, 134-141. https://doi.org/10.31258/unricsagr.1a18

Nuswantara, B.N., Hartono, G., \& Prihtant, T, M. (2016). Analisis Kelayakan Ekonomiusaha Tani Kedelai Di Desa Kebonagung Kabupaten Grobogan. Proseding Konser Karya Ilmiah Nasional Vol. 2, Agustus 2016 ISSN: 2460-5506 
Putri, R., Murdani, M., \& Fadli, F. (2015). Analisis Efisiensi Teknis Pada Usahatani Kedelai (Glycine $\max ($ L.) Merril) Di Kecamatan Peudada Kabupaten Bireuen, Aceh. Jurnal Agrium Unimal, 12(1), Article 1. https://doi.org/10.29103/agrium.v12i1.381

Styawan, A.A., Marwanti, S \& Ani, S.W. (2018) Analisis Usahatani Kedelai Di Kecamatan Sambirejo Kabupaten Sragen. Agrista : Vol. 6 No. 4 Desember 2018 : 1-10 ISSN : 2302-1713

Suciaty, T., \& Hidayat, Y. R. (2019). Analisis Efisiensi Ekonomi Penggunaan Faktor-Faktor Produksi pada Usahatani Kedelai (Glycine Max L. Merrill) (Studi Kasus di Desa Bantarwaru Kecamatan Gantar Kabupaten Indramayu). Jurnal Ekonomi Pertanian Dan Agribisnis, 3(4), 662-670. https://doi.org/10.21776/ub.jepa.2019.003.04.1

Supartama, M., Antara, M., \& Rustam, A.R. (2013). Analisis Pendapatan Dan Kelayakan Usahatani Padi Sawah Di Subak Baturiti Desa Balinggi Kecamatan Balinggi Kabupaten Parigi Moutong. Jurnal Agrotekbis. 1(2) :166-172

Tahir, A.G., Darwanto, D.H., Mulyo, J.H., \& Jamhari. (2010). Analisis Efisiensi Produksi Sistem Usahatani Kedelai Di Sulawesi Selatan. Jurnal Agro Ekonomi, Volume 28 No.2,Oktober 2010 :133-151

Widonoto, H., \& Arifin, M. Z. (2008). Upaya Peningkatan Produksi Kedelai (Glycine Max Merr.) Sebagai Upaya Meningkatkan Keuntungan Petani Di Jawa Timur. JSEP (Journal of Social and Agricultural Economics), 2(1), 38-47. 